\title{
Endogenous development of Goussia trichogasteri (Apicomplexa: Eimeriidae) in the intestine of gourami Trichogaster trichopterus
}

\author{
Soo Hyun Kim, Ilan Paperna \\ Department of Animal Sciences, Faculty of Agriculture of the Hebrew University of Jerusalem, Rehovot 76-100, Israel
}

\begin{abstract}
Life-cycle stages of Goussia trichogasteri Székely \& Molnár, 1992 from farm-reared gourami Trichogaster trichopterus in Israel were studied by light and electron microscopy. Intestinal stages were all epicytoplasmic. The parasitophorous envelope of mature meronts and macrogamonts was attached to the epithelial host cell by several extended finger-like projections, which lifted the encased parasite above the brush-border layer. Sections of microgamonts revealed up to 9 microgametes. In the macrogamonts, dense bodies were formed within endoplasmic reticulum cisternae.
\end{abstract}

KEY WORDS: Development - Eimeriidae - Goussia trichogasteri - Trichogaster trichopterus Ultrastructure

\section{INTRODUCTION}

Székely \& Molnár (1992) described Goussia trichogasteri from aquarium-bred golden gourami Trichogaster trichopterus trichopterus in Hungary. They noted epicytoplasmic endogenous development in the midgut but did not provide details. Gourami are reared commercially at several farms in Israel. Coccidial infections were first diagnosed in fish demonstrating severe pathology associated with herpes-like viruses (demonstrated by electron microscopy) (Kim \& Paperna unpubl.). Subsequently, seemingly healthy fish were also found to be infected.

In the present study, endogenous stages are described using both light microscopic histology and electron microscopy.

\section{MATERIALS AND METHODS}

Oocysts were measured live, in preparations made from feces or posterior intestinal contents. Samples from the gut tissue were fixed for histology in $10 \%$ neutral buffered formalin and embedded in glycol methacrylate medium (GMA; Agar Comp., UK). Sections 3 to $4 \mu \mathrm{m}$ thick were cut with a glass knife on a Sorval
JB4 microtome and stained with Mayer's haemalum using eosin or eosin and phloxin as counterstains. For transmission electron microscopy, gut segments were fixed in Karnowski for $24 \mathrm{~h}$ at $4{ }^{\circ} \mathrm{C}$, rinsed repeatedly in cacodylate buffer $(0.1 \mathrm{M}$, ph 7.4) and postfixed in $1 \%$ osmium tetroxide, in the same buffer, for $1 \mathrm{~h}$. After rinsing in the same buffer, the material was dehydrated in graded alcohols and embedded in Epon. Thin sections cut on a Reichert Ultracut ultratome with a diamond knife were stained on grid with uranyl acetate and lead citrate and examined with a Jeol $100 \mathrm{CX}$ TEM.

\section{RESULTS}

\section{Oocyst measurements}

Unsporulated oocysts (Figs. 1 \& 2) were oval to spherical, with sizes ranging from $11.4 \times 10.6$ to $16.1 \times$ $15.7 \mu \mathrm{m}(\mathrm{n}=5)$, and a $7.2-11.9 \times 6.8-10.2 \mu \mathrm{m}$, sporoblast $(\mathrm{n}=9)$. Sporulated oocyst sizes ranged from 14.9 $\times 14.5$ to $19.5 \times 19.1 \mu \mathrm{m}(\mathrm{n}=10)$. Sporozoite-containing sporocysts ranged from $3.8 \times 2.8$ (in the smallest oocysts) to $5.9 \times 3.8 \mu \mathrm{m}(\mathrm{n}=20)$. Giemsa-stained sporozoites were $5.3-6.1 \times 1.5-1.8 \mu \mathrm{m}(\mathrm{n}=10)$. 


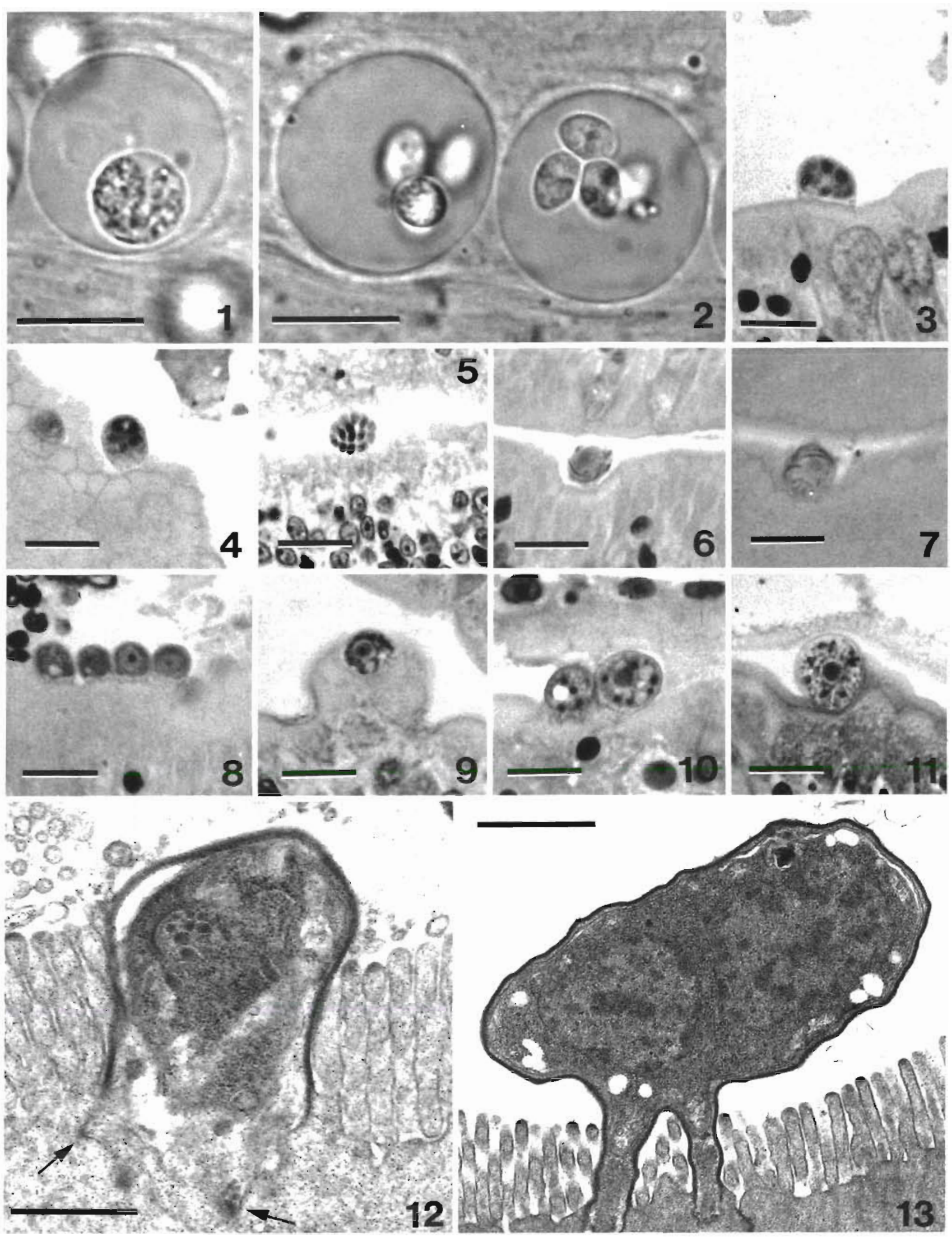


Sporulation was endogenous, in the posterior portion of the gut.

\section{Light microscopic histology of endogenous stages}

Endogenous development occurred in the hind portion of the gut. All observed developmental stages were epicytoplasmic, located at or above the brush border, on the surface of the gut epithelium (Figs. 3 to 11). In cross section, $2.9-5.1 \times 2.7-4.5 \mu \mathrm{m}$ meronts exhibited 2 to 4 nuclei, and $7.0-9.0 \times 4.7-6.9 \mu \mathrm{m}$ contained 5 to 7 nuclei (Figs. 3 \& 4). Segmenting meronts revealed up to 17 merozoites (Fig. 5). Free merozoites were $2.2-3.4 \times 2.2-2.4 \mu \mathrm{m}$ in size. Microgamonts, $5.6-9.7 \times 5.0-9.0 \mu \mathrm{m}$, revealed up to 9 microgametes (Figs. $6 \&$ 7). Young macrogamonts, 3.6-6.7 $\times 2.7-5.8$ $\mu \mathrm{m}$, contained little or no amylopectin granules, with nuclei exhibiting a distinct nucleolus (Figs. 8 \& 9). Mature macrogamonts, 5.8-9.2 × 4.5-7.9 $\mu \mathrm{m}$ (Fig. 10), and zygotes or young oocysts, $7.6-11.2 \times 6.3-11.2 \mu \mathrm{m}$ (Fig. 11), were filled with amylopectin granules. Young oocyst nuclei were homogeneously dense.

\section{Electron microscopic observations}

The parasites, enclosed in parasitophorous envelopes (PEs) were located at or above the gut epithelial cell brush border (Figs. 12 to 19). The PE (Figs. $14 \& 15$ ) consisted of the host cell wall apposed to that of the parasitophorous vacuole (PV). PVs of trophozoites and early gamonts formed a broad juncture containing several invaginations with a filamentous axis (see 'axial invaginations'; Figs. $12,16 \& 17$ ). In the more developed meronts and gamonts, the connection between the PVs and the host cell cytoplasm was reduced to a few finger-like projections with smooth junctures (Figs. 13 to 15, 18). Macrogamont PVs contained foamy, globular sediment (Figs. 16, 17 \& 19).

The merozoite pellicle was retained to maturity in both meronts (Figs. 14 \& 15) and macrogamonts (Fig. 18). Multinucleated meronts had a ribosome-rich cyto plasm containing a fair amount of amylopectin granules (Figs. 13 to 15). Young macrogamonts still retained an apical complex and micronemes (Fig. 16). Macrogamont cytoplasm contained extensive endoplasmic reticulum with many cisternae, and a few lipid vacuoles (Figs. 16 to 18 ). As the macrogamonts matured, electron-dense bodies appeared within the cisternae (Fig. 18), gradually increasing in size (Figs. 19 \& 20 ), and the cytoplasm became loaded with amylopectin granules, accompanied by a few canaliculi (Fig. 19). In the zygote, the beginning of wall formation was observed with the separation of the outer pellicular wall from the oocyst cytoplasm plasmalemma (Fig. 20)

\section{DISCUSSION}

Coccidia from gourami raised in Israel conform in their oocyst and sporocyst sizes to those of Goussia trichogasteri described by Székely \& Molnár (1992) from aquarium-raised gourami in Hungary. The 2 coccidia are therefore proposed to be of the same species.

Mature stages of Goussia trichogasteri, like serval other epicytoplasmic species in fish, form a peculiar attachment through several isolated finger-like projections. The way in which such an attachment is formed has not yet been demonstrated. However, Lukes (1992) has proposed a possible series of events via which this type of attachment could evolve.

Microgamonts of Goussia trichogasteri produce fewer microgametes than many other piscine coccidia (for example G. carpelli, G. janae or G. pannonica; Lukes \& Dyková 1990, Steinhagen 1991, Lukes 1992).

Epicytoplasmic coccidia of lower vertebrates seem to be of polyphyletic origin. Those found in reptiles conform to the rest of the reptilian (as well as higher vertebrate) eimeriid coccidia in the type of wall-forming (WF) bodies present in their macrogamonts (Paperna 1989). Epicytoplasmic piscine coccidia differ among themselves as well as from those found in reptiles by their morphological and fine-structural characteristics. Piscine epicytoplasmic species form either Goussiatype (Goussia spp.; Lukes \& Dyková 1990, Lukes 1992, Székely \& Molnár 1992) or Eimeria-like sporocysts with an apical opening, and with or without a Stieda body-like plug (Epieimeria spp. and Eimeria s. 1. spp.; Dyková \& Lom 1981, Lom \& Dyková 1981, 1982. Daoudi et al. 1987, Landsberg \& Paperna 1987). Some sporulate in the intestine (Epieimeria spp., E. catalana and G. trichogasteri; Lom \& Dyková 1981, 1982, this study), whereas others sporulate exogenously (Landsberg \& Paperna 1987, Lukes 1992). Interspecific variations in the structure of the PE, the PV juncture

Figs. 1 to 13. Goussia trichogasteri. Fig. 1. Unsporulated oocysts from the gut content. Scale bar $=10 \mu \mathrm{m}$. Fig. 2 . Sporulated oocyst from the gut content. Scale bar $=10 \mu \mathrm{m}$. Figs. 3 to 11 Light microscopic views of endogenous stages in a histological section of the hindgut. Scale bars $=10 \mu \mathrm{m}$. Figs. 3 to 5. Dividing meronts. Figs. 6 \& 7. Microgamonts with microgametes. Fig. 8 . Young macrogamonts. Figs. $9 \& 10$. Mature macrogamonts. Fig. 11. Zygote (young oocyst). Figs. 12 \& 13. Electron micrographs of endogenous stages from the hindgut. Scale bars $=1 \mu \mathrm{m}$. Fig. 12 . Newly established trophozoite (arrows: axial invaginations). Fig. 13. Young meront 

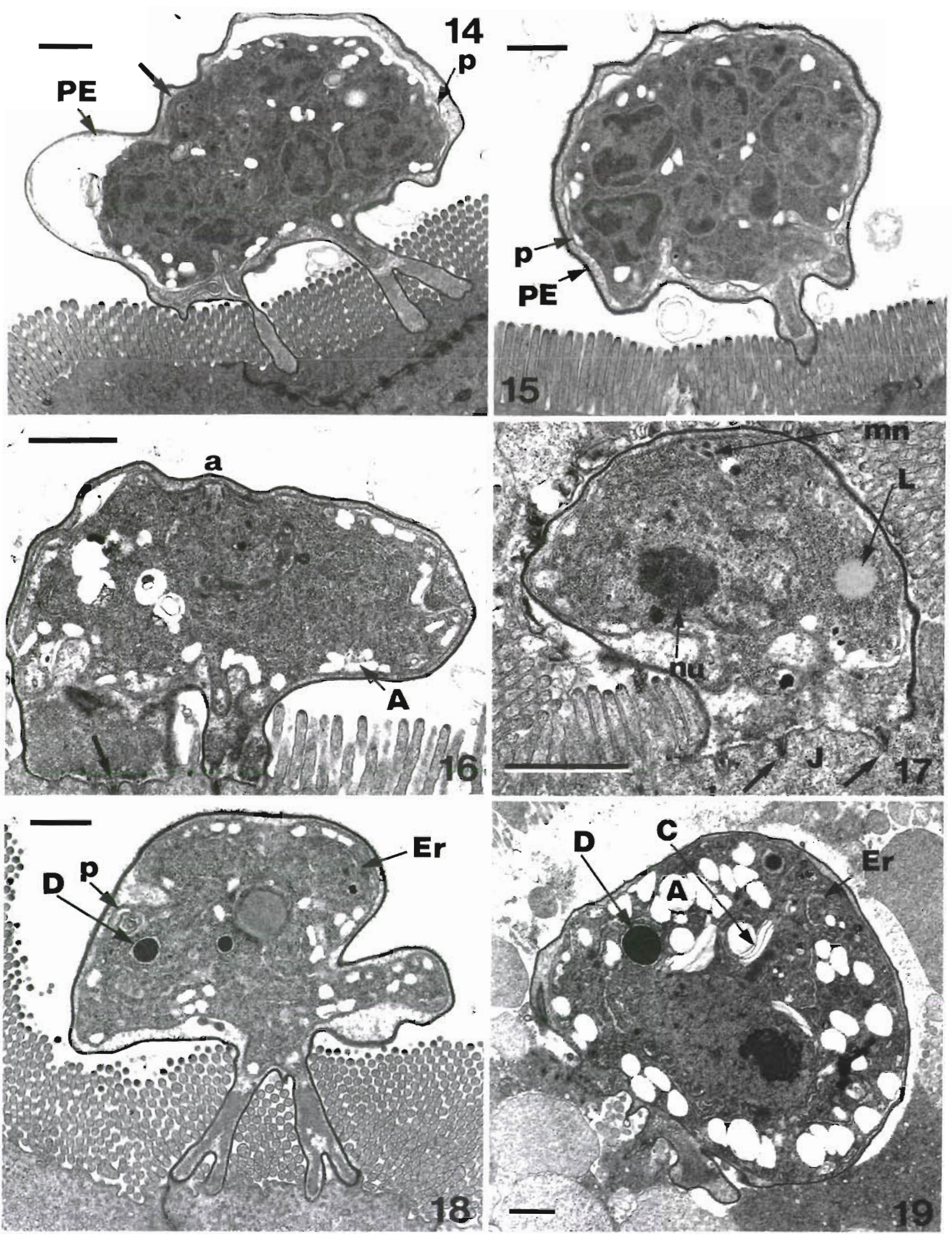


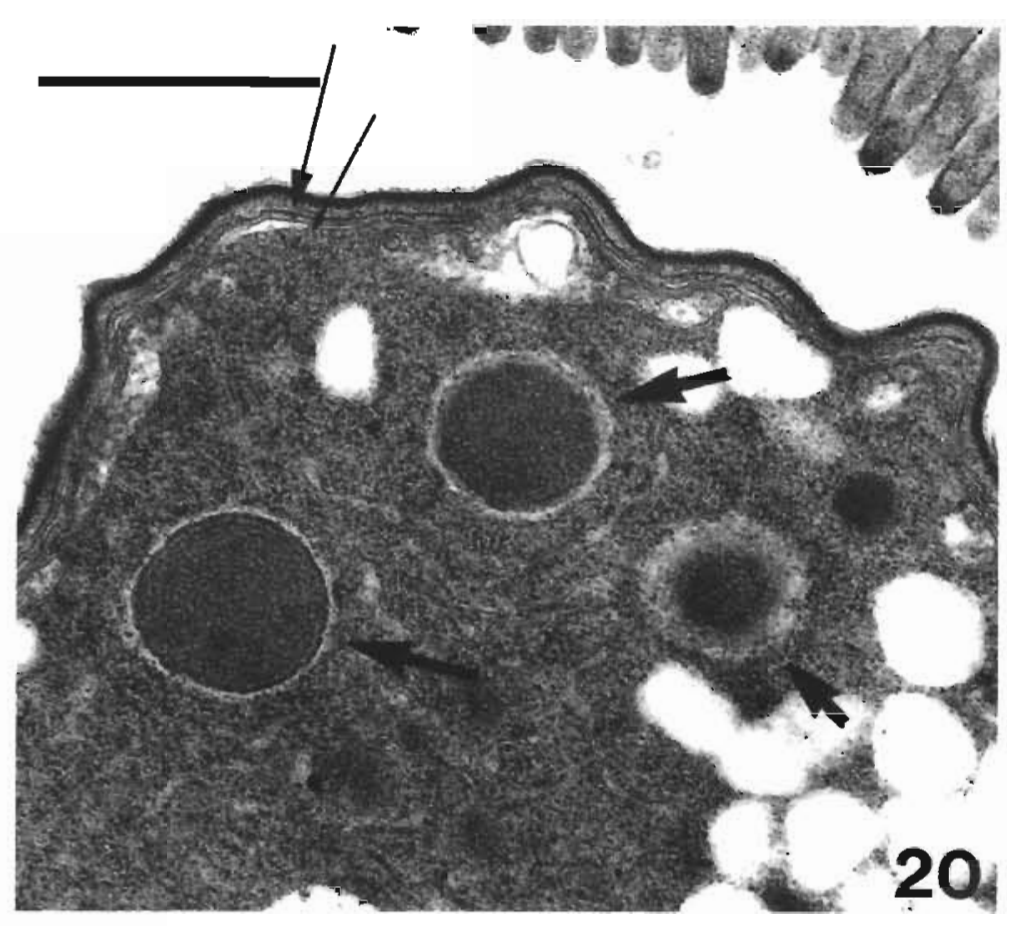

Fig. 20. Goussia trichogasteri. Electron micrograph. Enlarged view of a zygote's wall membranes, already duplicated (fine arrows). Note stages in the formation of dense bodies within cisternae (bold arrows). Scale bar $=1 \mu \mathrm{m}$

with the host cell cytoplasm and the nature of the axial invaginations and oocyst wall formation have already been discussed in the context of fine-structural descriptions of other epicytoplasmic piscine species (Molnár \& Baska 1986, Paperna \& Landsberg 1987. Jastrzebski \& Komorowski 1990, Paperna 1991, Lukes 1992, Kim \& Paperna 1992). It is only in the macrogamonts of Eimerias. 1. vanasi that 2 types of WF bodylike organelles occur, in a pattern reminiscent of those of higher vertebrate coccidia (Kim \& Paperna 1992). Macrogamonts of the other piscine intracytoplasmic species, like most ultrastructurally studied intracytoplasmic species (such as G. iroquoina: Paterson \& Desser 1981, G. carpelli: Steinhagen 1991), from dense bodies which may (Jastrzebski \& Komorowski 1990) or may not (Desser \& Li 1984, Paterson \& Desser 1984, Davies 1990 ) be functionally analogous to higher vertebrate coccidia WF bodies. In $G$. trichogasteri, dense bodies are formed within the endoplasmic reticulum cisternae, resembling the true type 2 WF bodies, as well as the type-2-like WF bodies of E. vanasi (Paperna 1990, Kim \& Paperna 1992).

\section{LITERATURE CITED}

Daoudi, F., Radujkovic, B., Marques, A., Bouix, G. (1987). Nouvelles espèces de Coccidies (Apicomplexa, Eimeriudae) des genres Eimeria Schneider, 1875, et Epieimeria Dyková et Lom, 1981, parasites de poissons marins de la baie de Kotor (Yougoslavie). Bull. Mus. natn. Hist. nat., Paris, 4ème sér., 9, section A 2: 321-332

Davies, A. (1990). Ultrastructural studies on the endogenous stages of Eimeria variabilis (Thelohan, 1893) Reichenow, 1921, from Cottus (Taurulus) bubalis Euphrasen (Teleostei: Cottidae). J. Fish Dis. 13: 447-461

Desser, S. S., Li, L. (1984). Ultrastructural observations on the sexual stages and oocyst formation in Eimeria laureleus (Protozoa, Coccidia) of perch, Perca flavescens from L. Sasajebwum, Ontario. Z. Parasitenk. 70: 153-164

Dyková, I., Lom, J. (1981). Fish coccidia: critical notes on life cycles, classification and pathogenicity. J. Fish Dis. 4: $487-505$

Jastrzebski, M., Komorowski, Z. (1990). Light and electron microscopic studies on Goussia zarnowskii (Jastrzebski, 1982): an intestinal coccidium parasitizing the threespined stickleback, Gasterosteus aculeatus (L.). J. Fish Dis. 13: 1-12

Kim, S. H., Paperna, I. (1992). Fine structure of epicytoplasmic stages on Eimeria s. l. vanasi from the gut of cichlid fish. Dis. aquat. Org. 12: 191-197

Figs. 14 to 19. Goussia trichogasteri. Electron micrographs of endogenous stages from the hindgut. Scale bars = $1 \mu \mathrm{m}$. Figs. 14 \& 15. Dividing meronts. p: pellicle; PE: parasitophorous envelope; arrow: apical complex. Figs. 16 \& 17 . Young macrogamonts in the PV with broad junction ( $\mathrm{J}$ ) and axial invaginations (arrows), with an apical complex (a), micronemes (mn), amylopectin granules (A) and a nucleus with large nucleolus (nu). Fig. 18. Macrogamont in the PE connected through prolongated projections. Fig. 19. Mature macrogamont. A: amylopectin granules; C: canaliculi; D: dense body inside a cisterna; Er: endoplasmicreticulum; L: lipid vacuole; $\mathrm{p}$ : pellicle. 
Landsberg, J. H., Paperna, I. (1987). Intestinal infections by Eimeria s. 1. vanasi n. sp. (Eimeriidae, Apicomplexa, Protozoa) in cichlid fish. Annls Parasitol. hum. comp. 62: $283-293$

Lom, J., Dyková, I. (1981). New species of Eimeria from marine fish. Z. Parasitenk. 66: 207-220

Lukes, J. (1992). Life cycle of Goussia pannonica (Molnár, 1989) (Apicomplexa. Eimeriorina) an extracytoplasmic coccidium from the white bream Blicka bjorkna. J Protozool. 39: 484-494

Lukes, J., Dyková, I. (1990). Goussia janae n. sp. (Apicomplexa, Eimeriorind) in dace Leuciscus leuciscus and chub L. cephalus. Dis. aquat. Org 8: 85-90

Molnár. K., Baska, F. (1986). Light and electron microscopic studies on Epieimeria anquillae (Leger \& Hollande, 1922), a coccidium parasitiring the European eel, Anguilla anguilla L. J. Fish Dis. 9: 99-110

Paperna, I. (1989). Ultrastructure of Eimeria s. l. sp. infecting the microvillar zone of the intestinal epithelium of gerkoes. Annls Parasitol. hum. comp. 84: 89-99

Paperna, I. (1990). Fine structure of the gamonts of Eimeria (s. l.) vanasi, a coccidium from the intestine of cichlid fishes. Dis. aquat. Org. 9: 163-170

Paperna, I. (1991). Fine structure of Eimeria (s. 1.) vanasi me-

Responsible Subject Editor: W. Körting, Hannover, Germany rogony stages in the intestinal mucosa of cichlid fishes. Dis, aquat, Org. 10: 195-201

Paperna, I., Landsberg, J. H. (1987). Tubular formations extending from parasitophorous vacuoles in gut epithelial cells of cichlid fish infected by Eimeria (s. 1.) vanasi. Dis. aquat. Org. 2: 239-242

Paterson, W. B., Desser, S. S. (1981). Ultrastructure of macrogametogenesis, macrogametes and young oocysts of Eimeria iroquoina Molráar and Fernando, 1974 in experimentally infected fathead minnows (Pimephales promelas, Cyprinidae). J. Pardsitol.. 67: 49łj-504

Paterson, W. B., Desser, S. S. (1984). Ultrastructural observations on fertilization and sporulation in Goussia iroquoina (Molnár and Fernando, 1974) in experimentally infected fathead minnows (Pimephales promelas, Cyprinidae). J. Porasitol. 70: 703-711

Steinhagen, D. (1991). Ultrastructural observations on merogonic and gamogonic stages of Goussia carpelli (Apicomplexa, Coccidia) in experimentally intected com mon carp Cyprinus carpio. Eur. J. Protistol. 27: 71-78

Székely, C., Molnár, K. (1992). Goussia trichogasteri n. sp. (Apicomplexa: Eimeriidae) infecting the aquariumcultured golden gourami Trichogaster trichopterus trichopterus. Dis. aquat. Org. 13:79-81

Manuscript first received: June 10,1993

Revised version accepted: August 10, 1993 